\title{
Pelatihan Penyusunan Soal High Order Thinking Skill (HOTS) bagi Guru-Guru Fisika di SMA Di Kota Depok
}

\author{
Tri Isti Hartini ${ }^{1}$, Martin ${ }^{2}$ \\ 1,2 Universitas Muhammadiyah Prof.DR. Hamka Jakarta \\ E-mail: ${ }^{1}$ istifisika@gmail.com, ${ }^{2}$ martinclicking@gmail.com
}

\author{
INFO ARTIKEL ABSTRAK
}

\section{Available online}

URL:

https://journal.stkipnurulhuda.ac.id/ index.php/JIMi/article/view/453

\section{How to cite (APA):}

Hartini, T., \& Martin, M. (2019).

Pelatihan Penyusunan Soal High Order Thinking Skill (HOTS) bagi Guru-Guru Fisika di SMA Di Kota Depok. Jurnal Indonesia Mengabdi, 1(1), 27-29.

This work is licensed under a Creative Commons Attribution 4.0 International License

\begin{abstract}
Abstrak
Kegiatan pengabdian ini dilatar belakangi oleh semakin berkembangnya system penilaian pembelajaran di lembaga pendidikan. Kenyataan di lapangan, soal-soal cenderung lebih banyak menguji aspek ingatan. Oleh karena itu, dirasanya guru-guru, terutama guru fisika perlu dilakukan pelatihan mengenai pembuatan soal HOTS. Dalam kegiatan pengabdian ini, sesi pertama membahas tentang soal HOTS dalam tataran teoritis yang meliputi pengertian, langkah-langkah pelaksanaan, serta kelebihannya. Sesi kedua merupakan pendalaman terhadap materi yang diikuti dengan latihan tentang bagaimana menerapkan soal-soal HOTS tersebut dalam kegiatan belajar mengajar. Metode yang digunakan dalam melaksanakan kegiatan pengabdian ini adalah metode ceramah, tanya jawab, diskusi, dan praktek langsung. Berdasarkan pengamatan selama kegiatan pengabdian kepada masyarakat berlangsung, diperoleh beberapa hasil yang positif, diantaranya adalah: 1). Para peserta menunjukkan perhatian yang sangat tinggi terhadap materi pengabdian yang disampaikan oleh tim pengabdian. 2). Para peserta menunjukkan reaksi yang positif terhadap cara mengembangkan soal HOTS. 3). Para peserta aktif bertanya dan mengungkapkan masalah-masalah yang dialaminya selama ini dan mereka bersemangat untuk dapat membuat soal HOTS dalam penilaian. Hasil dari kegiatan pengabdian ini adalah bertambahnya wawasan para guru fisika yang tergabung dalam MGMP Fisika Kota Depok mengenai pembuatan soal HOTS.
\end{abstract}

Kata kunci: Penilaian, Soal HOTS

\begin{abstract}
This service activity was motivated by the growing system of learning in educational institutions. Reality in the field, questions that are more discussed aspects of memory. Therefore, he felt that teachers, especially physics teachers, needed to be trained in making HOTS questions. In this service activity, the first session discussed the issue of HOTS in a discussion that included the understanding, steps of implementation, and its advantages. The second session was a deepening of the material followed by training on the questions raised about HOTS in teaching and learning activities. The method used in carrying out this service activity is the lecture method, question and answer, discussion, and direct practice. Based on observations during the community service activities, several positive results were obtained, which were expected to be: 1). The participants showed very high attention to the service material delivered by the service team. 2). The participants showed positive reactions to how to develop HOTS questions. 3). The active participants asked and revealed the problems they had experienced so far and they were happy to be able to make HOTS questions in the discussion. The results of this service activity add insight to physics teachers who are members of the Depok City Physics MGMP about making HOTS questions.

Keywords: Assessment, HOTS quetion
\end{abstract}




\section{PENDAHULUAN}

Peserta didik tingkat SMA harus mulai dilatih berpikir tingkat tinggi sesuai dengan usianya. Melatih peserta didik untuk terampil ini dapat dilakukan guru dengan cara melatihkan soal-soal yang sifatnya mengajak siswa berpikir dalam level analisis, sintetis dan evaluasi. Keterampilan berpikir tingkat tinggi atau "Higher Order Thinking Skill" (HOTS) jika ditinjau dari ranah kognitif pada Taksonomi Bloom, berada pada level analisis, sintesis, dan evaluasi. Mengembangkan butir soal harus mengikuti rambu-rambu yang ditetapkan, baik untuk penulisan soal secara umum maupun rambu-rambu berdasarkan tingkat berpikir peserta didik yang mengerjakan soal. Untuk pembuatan soal HOTS, penulis soal biasanya merasa agak kesulitan dalam mengkreasinya.

Disamping sulit menentukan perilaku yang diukur juga sulit dalam merumuskan masalah yang dijadikan dasar pertanyaan. Untuk membantu guru dalam meningkatkan keterampilan berpikir peserta didik melalui soal-soal, akan dijabarkan bagaimana cara mengembangkan soal-soal fisika yang termasuk dalam kategori HOTS berdasarkan Taksonomi Bloom. HOTS Berdasarkan Taxonomi Bloom, masuk pada tiga level tertinggi yaitu analisis, sintesis, dan evaluasi. Dalam soal-soal pembelajaran Fisika keterampilan analisis, sintesis, dan evaluasi dapat dikembangkan misalnya dengan menyajikan stimulus dalam bentuk data percobaan, grafik, gambar suatu fenomena atau deskripsi singkat suatu fenomena yang selanjutnya digunakan siswa untuk menjawab soal.

Soal-soal untuk pengujian ini dapat dibuat dalam bentuk soal pilihan ganda maupun uraian. Teknik penulisan soal HOTS secara umum hampir sama dengan teknik penulisan soal-soal biasa tetapi karena peserta didik diuji pada proses analisis, sintesis atau evaluasi, maka pada soal harus ada komponen yang dapat dianalisis, disintesis atau dievaluasi. Komponen ini di dalam soal dikenal dengan istilah stimulus. Selain itu soal-soal Fisika juga harus menguji keterampilan proses Fisika, karena pendekatan pembelajaran yang dianjurkan adalah pendekatan keterampilan proses. Oleh karena itu kata kerja yang dipilih pada ranah kognitif diutamakan yang sesuai dengan keterampilan proses. Untuk soal-soal Fisika, guru dapat memilih kata kerja yang sesuai dengan konsep Fisika yang dipelajari peserta didik dan sesuai dengan indikator hasil belajar yang diturunkan dari kompetensi dasar yang harus dicapai peserta didik pada setiap konsep Fisika.

\section{METODE PELAKSANAAN}

Metode yang dilaksanakan pada kegiatan pengabdian ini adalah: metode ceramah, diskusi dan demontrasi atau praktek langsung. Materi ceramah antara lain tentang soal-soal HOTS dan cara penyusunan soal HOTS. Selanjutnya guru-guru langsung praktek menyusun soal HOTS dengan didampingi oleh instruktur dosen dan mahasiswa. Terakhir dilakukan uji coba soal dengan peserta pelatihan sebagai sampel. Langkah-langkah pelaksanaan kegiatan adalah sebagai berikut:

1. Membahas tentang soal HOTS dalam tataran teoritis yang meliputi pengertian, langkah-langkah pelaksanaan, serta kelebihannya.

2. Merupakan pendalaman terhadap materi yang diikuti dengan latihan tentang bagaimana menerapkan soal-soal HOTS tersebut dalam kegiatan belajar mengajar.

\section{HASIL DAN PEMBAHASAN}

Hasil yang telah dicapai dari pelatihan penyusunan soal HOTS ini adalah keterampilan guru-guru SMA dalam menyusun soal HOTS. Namun karena keterbatasan waktu, tim belum menguji coba kualitas soal seperti uji validitas dan reliabilitas dari soal yang telah dikembangkan oleh peserta. Dapat diringkas bahwa, berdasarkan pengamatan selama kegiatan pengabdian kepada masyarakat berlangsung, diperoleh beberapa hasil yang positif, diantaranya adalah:

1. Para peserta menunjukkan perhatian yang sangat tinggi terhadap materi pengabdian yang disampaikan oleh tim pengabdian.

2. Para peserta menunjukkan reaksi yang positif terhadap cara mengembangkan soal HOTS. 
3. Para peserta aktif bertanya dan mengungkapkan masalah-masalah yang dialaminya selama ini dan mereka bersemangat untuk dapat membuat soal HOTS dalam penilaian. Hasil dari kegiatan pengabdian ini adalah bertambahnya wawasan para guru fisika yang tergabung dalam MGMP Fisika Kota Depok mengenai pembuatan soal HOTS.

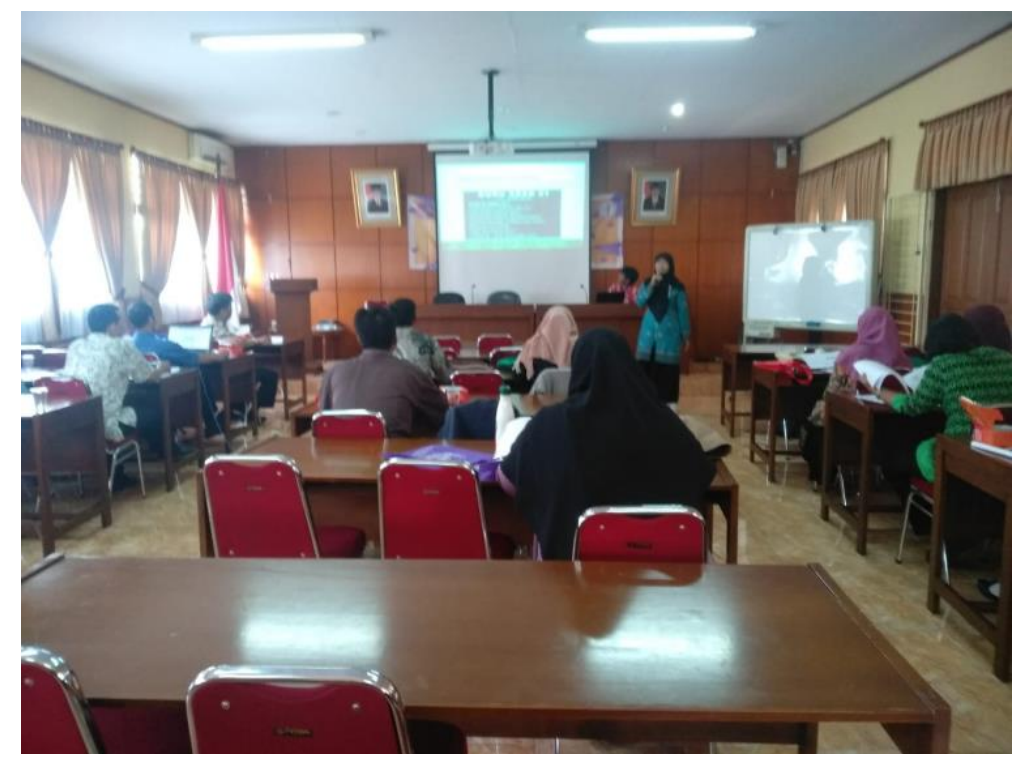

Gambar 1. Penyampaian materi oleh TIM PKM

\section{SIMPULAN}

Pelatihan penyusunan soal HOTS dalam perkembangan sistem penilaian pembelajaran sangat penting terus dilakukan. Guru-guru yang mengikuti pelatihan ini sangat antusias dan sangat terbantukan sekali dalam mengembangkan soal HOTS. Dengan pelatihan ini mereka mendapatkan penjelasan yang sangat baik. Kumpulan soal-soal HOTS mata pelajaran Fisika SMA yang mereka kembangkan juga sangat menarik. Dari kegiatan pengabdian ini disarankan, perlu dilakukan pelatihan penyusunan soal HOTS berikutnya dari mulai pengembangan soal sampai menguji kualitas soal HOTS, dengan begitu akan terlihat soal-soal yang telah teruji tingkat validitas dan reliabilitas soal yang dikembangkan oleh peserta. Peserta juga bias diajak belajar bagaimana cara menguji kualitas soal yang dikembangkan.

\section{DAFTAR PUSTAKA}

Arifin, Z. (2014). Evaluasi Pembelajaran. Bandung : PT Remaja Rosdakarya.

Arikunto, S. (2009). Dasar-Dasar Evaluasi Pendidikan (Edisi Revisi). Jakarta: PT Bumi Aksara.

Costa, A.L. and Presseisen, B.Z. (1985). Glossary of Thinking Skill, in A.L. Costa (ed). Developing Minds: A Resource Book for Teaching Thinking,Alexandria: ASCD.

PISA (2012) Result:What Student Know and Can Do-Student Performance in Reading Mathematics and Science. Volume 1. OECD: 2014

Iswadi, H. (2016). Sekelumit Dari Hasil PISA 2015 Yang Baru Dirilis . Retrieved from Universitas Surabaya: http://www.ubaya.ac.id/2014/content/articles detail/230/Overview-of-the-PISA2015-results-that-have-just-been-Released.html

Sudjana, N. (2010). Penilaian Hasil Proses Belajar Mengajar. Bandung: PT Remaja Rosdakarya.

Sukardi. (2008). Evaluasi Pendidikan Prinsip dan Operasionalnya. Yogyakarta : bumi aksara.

Suwandi, S. (2010). Model Assesmen Dalam Pembelajaran. Surakarta: Yumma Pustaka. 